\title{
MARCIN DęBICKI
}

UNIWERSYTET WROCEAWSKI

E-MAIL: MD4@WP.PL

\section{ZA GÓRAMI, ZA LASAMI... ALBO GRANICA JAK NIEWIDZIALNY MUR. ENDEMIZM ZAKARPACKIEGO ODCINKA POGRANICZA UKRAIŃSKO-POLSKIEGO}

\section{Wprowadzenie}

Celem artykułu jest wprowadzenie kwestii zakarpackiego odcinka pogranicza ukraińsko-polskiego w obręb zainteresowań polskiej socjologii pogranicza przez zarysowanie specyfiki tego obszaru, ze szczególnym uwzględnieniem niewielkiej wsi Łubnia (ukr. Лубня, Lubňa), położonej przy granicy z Polską. Do ich podjęcia skłania fakt, że Zakarpacie - jeden z obwodów Ukrainy sąsiadujących z RP - przede wszystkim z racji nieprzepuszczalności owej nieodległej granicy, zajmuje peryferyjne miejsce w świadomości Polaków, także tych zainteresowanych całościowo ujmowanym transgraniczem polsko-ukraińskim. Jeśli chodzi o samą Łubnię, przyjmując perspektywę socjologii pogranicza, dostrzegamy, że osadę tę, choć od granicy dzielą ją niecałe trzy kilometry, charakteryzuje brak interakcji transgranicznych i, w konsekwencji, całkowita izolacja od rzeczywistości $\mathrm{z}$ drugiej strony kordonu. Można więc powiedzieć, że Łubnię od Polski dzieli tak niewiele, a zarazem tak wiele.

Inaczej patrząc na problem, zauważamy, że niniejszy artykuł jest próbą przybliżenia obszaru, który dla socjologii pogranicza może być interesujący właśnie dlatego, iż stanowi ilustrację stosunków społecznych i towarzyszących im okoliczności w sytuacji bardzo mocno utrudnionych (w praktyce: często po prostu nie do zrealizowania) bezpośrednich kontaktów transgranicznych. Na przykładzie Łubni i - szerzej - Zakarpacia można zatem zauważyć, jak wygląda realnie (administracyjnie) istniejące sąsiedztwo w sytuacji braku punktu odpraw, który to stan warunkowany jest oporem (lub przynajmniej brakiem woli zmian) ze strony różnych aktorów spo- 
łecznych. Prezentowane rozważania lokują się zatem w ramach tego, co antropologia polityczna ujmuje jako wpływ instytucji państwowych, określonej linii politycznej, na rzeczywistość danego obszaru [Wilson, Donnan 2000: 7] $]^{1}$.

Podstawą poniższej refleksji są informacje zebrane w sierpniu i listopadzie 2014 roku, a także w listopadzie 2015 roku$^{2}$, podczas trzech kilkudniowych pobytów autora artykułu w kilku wsiach Zakarpacia (Użok, Wołosianka, Werchowyna-Bystra, Stawne, Łubnia i Zahorb). Wspólną cechą tych miejscowości jest to, że od granicy z Polską dzieli je kilka (przeważnie nie więcej niż pięć) kilometrów. Lokalizacja ta jest czynnikiem w sposób zasadniczy warunkującym charakter materiału empirycznego, który pozyskano $\mathrm{w}$ ramach spontanicznych i metodologicznie luźnych rozmów z osobami dobranymi na zasadzie ich dostępności. Kluczowym zagadnieniem jest tu fakt interesowania się przez przybysza z Polski kwestiami dotyczącymi granicy Ukrainy z owym państwem (a więc i z Unią Europejską oraz NATO), i to w sytuacji trwania konfliktu zbrojnego w Donbasie. Wśród miejscowej ludności, prawdopodobnie nieprzyzwyczajonej do tego typu dociekań, mogłyby one budzić podejrzenia zasługujące na to, aby zrelacjonować je stosownym służbom, w związku z czym w interakcje te badacz wchodził ostrożnie, z pozycji turysty podejmującego przygodne, niezobowiązujące rozmowy. Inną, nie mniej ważną okolicznością determinującą sytuacje badawcze było to, że opisywany obszar (z przedłużeniem na nieodległej Słowacji) jest ważnym szlakiem przemytu towarów i ludzi do UE przez grupy zorganizowane. Przeprowadzenie pogłębionych studiów przypuszczalnie byłoby tu więc możliwe dopiero po (ewentualnym) zdobyciu odpowiednich zezwoleń od ukraińskich służb granicznych, którym podlega ów newralgiczny obszar, tymczasem większość referowanych tu spostrzeżeń została poczyniona w ramach wyjazdów prywatnych, a więc podjętych w wymiarze pozainstytucjonalnym.

Z faktem niemal zupełnej nieobecności omawianego obszaru w polskiej literaturze dotyczącej pogranicz wiąże się kwestia dostępnych badaczowi

1 Prezentowany artykuł jest dopełnieniem o perspektywę stricte zakarpacką kwestii już podjętych: charakterystyki transgranicza polsko-ukraińskiego na odcinku tak zwanego worka bieszczadzkiego, propozycji ram teoretycznych możliwych do zastosowania podczas badań nad ideą otwarcia przejścia granicznego Wołosate-Łubnia, jak również społecznych uwarunkowań niemożności realizacji tego pomysłu [Dębicki 2015b (tam też mapa opisywanego terenu - zob. s. 147); Dębicki 2015a; Dębicki, $\mathrm{w}$ druku].

2 Ostatni z tych wyjazdów był finansowany przez Ośrodek Badań Regionalnych i Obszarów Pogranicza Uniwersytetu Wrocławskiego. 
źródeł. Dokonując opisu XX-wiecznej Łubni i okolic, budującego szerszy kontekst dla współczesności, wykorzystano więc głównie materiały krajoznawcze publikowane na łamach półrocznika Towarzystwa Karpackiego „Płaj. Almanach Karpacki”3, jeśli zaś chodzi o teraźniejszość - sięgnięto także po wyimki z prasy lokalnej (i wspomniane obserwacje własne). Niedostatki literatury i warunkujące proces badawczy obostrzenia graniczne sugerują, aby zebrane informacje ujmować w ramach wstępnego, dość pobieżnego i fragmentarycznego rozpoznania sytuacji, przede wszystkim wysondowania odczuć mieszkańców Łubni i okolicznych wsi w „kwestiach transgranicznych", a więc jako część działań, które w naukach społecznych określa się mianem eksploracji [Babbie 2004: 111]. Jednocześnie, zdiagnozowana niemal całkowita nieobecność Polski w działaniach indagowanych osób, jak również tego samego rodzaju przypuszczenia niektórych rozmówców co do szerzej ujmowanej społeczności opisywanego obszaru (tj. doliny górnego Użu czy - mówiąc inaczej - zakarpackiego fragmentu pogranicza ukraińsko-polskiego), skłaniają do przypuszczenia, że ów - formalnie rzecz biorąc - niedoskonały metodologicznie materiał może mieć wartość cokolwiek większą niż eksploracja.

\section{Zakarpacie i sąsiedztwo „polsko-zakarpackie”}

Zakarpacie jest obwodem sąsiadującym z Polską na długości 33 kilometrów (co stanowi 6\% długości całej granicy polsko-ukraińskiej) przez główny grzbiet Karpat, jednak w obliczu wspomnianego braku punktu odpraw, który połączyłby tę część Ukrainy z Rzeczpospolitą, dla socjologów pogranicza sąsiedztwo to wydaje się mieć minimalne znaczenie. W publikacjach innego charakteru czasami wspomina się, że w efekcie nieprzepuszczalności granicy dochodzi do utrwalenia nieobecności Zakarpacia w świadomości Polaków [Przeciszewski 2007: 111]. Ranga obwodu jawi się jako niezbyt duża także na przykład w pracy analityka Ośrodka Studiów Wschodnich (OSW) - przede wszystkim ze względu na względnie wysoki poziom odrębności tego regionu od innych (poza północną Bukowiną) ziem Ukrainy Zachodniej [Olszański 2013: 14], a więc także wobec sąsiedniego obwodu lwowskiego (dawnej Galicji Wschodniej). Jest bowiem Zakarpacie obszarem, który - zanim stał się częścią ZSRR - łączyły tysiącletnie, silne

Argumenty na rzecz przydatności tego typu publikacji w pracy naukowej, w szczególności w odniesieniu do Karpat, przedstawiono w innym miejscu; zob. Dębicki 2015b: 150-153. 
i wielowymiarowe związki z Węgrami (a także, w okresie międzywojennym - z Czechosłowacją), sam zaś region nigdy nie był przedmiotem rywalizacji między siłami polskimi a (funkcjonującymi w tej czy innej postaci) ukraińskimi. W przeciwieństwie do pozostałego fragmentu interesującego nas pogranicza - które konstytuuje się za sprawą dawnych: Galicji Wschodniej i Zachodniej oraz Lubelszczyzny i Wołynia - sąsiedztwo „polsko-zakarpackie" nie jest zatem obciążone dramatycznymi wydarzeniami z (przede wszystkim) XX-wiecznej historii, co z pewnością ułatwiłoby nawiązanie kontaktów między ludnością z miejscowości rozdzielonych nieodległym bieszczadzkim grzbietem granicznym.

Specyfika obwodu ujawnia się także w tym, że choć jest on jednym z najmniejszych na Ukrainie, graniczy aż z czterema spośród jej siedmiu sąsiadów: Słowacją, Węgrami, Rumunią i Rzeczpospolitą. Z pierwszymi trzema łączy Zakarpacie dziewiętnaście przejść granicznych, rozlokowanych na długości $434 \mathrm{~km}$, co oznacza, że punkt odpraw do państwa członkowskiego UE występuje średnio co $23 \mathrm{~km}$ (przy czym, co warto podkreślić, niemała część linii oddzielającej region od Rumunii przebiega trudno dostępnymi grzbietami górskimi). „Takiej infrastruktury, sprawiającej, że granice nie stanowią bariery trudnej do przekroczenia, nie ma żaden obwód Ukrainy. Tu praktycznie każdy większy trakt wiodący do granicy kończy się przejściem umożliwiającym wjazd do sąsiedniego kraju, należącego do Unii Europejskiej" [Koprowski 2014: 14-15]. Z pierwszymi trzema z wymienionych państw łączą Zakarpacie - stanowiący niemałą część jego mieszkańców - miejscowi Węgrzy, Rumuni i Rusini (ci ostatni swych historycznych, religijnych i językowych pobratymców mają między innymi we wschodniej Słowacji, ale także, choć w dużo mniejszym zakresie, na polskiej Łemkowszczyźnie). Kazimierz Krzysztofek [2003: 20], powołując się na ustalenia antropologów, pisał, że „na niewielkim skrawku Ukrainy zakarpackiej (rejon Użhorodu) żyją 92 wspólnoty (nazywające siebie Rusinami, Hucułami, Łemkami, Bliachami, Wierchowińcami i innymi), mówiące własnymi dialektami nieraz znaczenie od siebie się różniącymi”.

Spośród wspomnianych zbiorowości na szczególną uwagę zasługują Rusini, którzy nie kryją swego ambiwalentnego stosunku do Ukrainy. Jak pisze Ewa Michna - jedna z nielicznych badaczek przybliżających polskiemu czytelnikowi rzeczywistość Zakarpacia - najbardziej radykalni liderzy owej grupy etnicznej „nie tylko nie identyfikują się z narodem ukraińskim, ale także nie utożsamiają się z państwem ukraińskim”. Jest ono dla nich bytem obcym, „okupującym rusińskie terytoria”, w którym są „według 
własnych ocen obywatelami drugiej kategorii, dyskryminowanymi przy obsadzie ważnych stanowisk w swoim regionie" [Michna 2004: 145-146]. Dosyć luźne związki z Ukrainą łączą jednak nie tylko działaczy rusińskich, ale także „zwykłych obywateli”. Jednocześnie jednak - jak piszą analitycy OSW - „fakt, że na początku 2014 roku, w chwili największego zagrożenia aktywnymi działaniami rosyjskimi podważającymi ukraińską integralność terytorialną, na Zakarpaciu nie doszło do zaktywizowania się tendencji separatystycznych”, jest jedną z okoliczności zaświadczających o tym, iż „separatyzm rusiński na Zakarpaciu obecnie nie jest poważnym zagrożeniem dla Ukrainy" [Żochowski, Iwański 2015: 4]. Na marginesie warto zaznaczyć, że na fali rosyjskiej agresji w opisywanym regionie zanotowano wzrost nastrojów proukraińskich, zauważalnych także w przestrzeni publicznej (na przykład pod postacią barw państwowych, malowanych w różnych, niekiedy dość przypadkowych miejscach).

Poza utrudnioną dostępnością, abstrakcyjność Polski można rozpoznać również w rozmowach z miejscową ludnością, szczególnie wtedy, gdy dotykają one tematów międzynarodowych, przede wszystkim kierunku wyjazdów zarobkowych. Wówczas to pojawiają się Węgry, Czechy i Słowacja jako państwa łatwiej dostępne z Zakarpacia, z którymi kontakty są uświęcone tradycją i rozmaitymi związkami, nie ma tam natomiast miejsca dla Polski. Wspomniane wrażenie potwierdza obecność spotykanych lokalnie samochodów na czeskich czy słowackich numerach rejestracyjnych i niemal zupełny brak pojazdów zarejestrowanych w Polsce. Warto dodać, że pojawiają się one w sąsiednim obwodzie lwowskim, skąd do przejścia drogowego do Polski (w Smolnicy) jest znacznie bliżej - zarówno w sensie przestrzennym, jak i psychospołecznym (warunkowanym historycznie), wzmacnianym przez czynnik geomorfologiczny, czyli przebieg granicy między obwodami wzdłuż stosunkowo wysokiego (przynajmniej 300 metrów ponad okoliczne wsie) grzbietu Bieszczad, izolującego Zakarpacie od Ziemi Lwowskiej.

W związku z orientacją mieszkańców Zakarpacia na Czechy, Słowację czy Węgry, jak również z uwagi na brak przejścia granicznego do Polski, łatwiej przyjdzie zrozumieć, że państwo to jest dla nich na tyle abstrakcyjne, $\mathrm{iż}$ - w przeciwieństwie do pozostałych sąsiadów obwodu - niekiedy nawet nie wymienia się go jako wzoru dla upragnionego kierunku, jaki powinien obrać ich obwód [por. Szczerek 2010: 166]. Jak się wydaje, pewną zmianę w tym względzie można obserwować na fali kryzysu, jaki dotknął Ukrainę po upadku reżimu prezydenta Janukowycza, jak również zaangażowania 
Warszawy po stronie Kijowa podczas wojny w Donbasie, odkąd Polska stała się na Zakarpaciu nieco mniej anonimowa. Sytuacja ta mogłaby dalej rozwijać się w tym kierunku, gdyby rzeczony region został połączony ze swym północnym sąsiadem punktem odpraw w Łubni - tym bardziej że akurat ziemie środkowej i wschodniej części pogranicza z Polską zamieszkuje ludność mająca stosunkowo słabe związki z Węgrami czy Słowacją. Tymczasem w obliczu braku wspomnianego przejścia sąsiedztwo „polsko-zakarpackie" pozostaje niemal wyłącznie bytem administracyjnym (o czym szerzej traktuje dalsza część artykułu).

Konsekwencje tego stanu rzeczy są odczuwalne także nad Wisłą, gdzie wiedza na temat opisywanego obwodu wydaje się być niszowa. Wyobraźnię pobudzają tu na przykład wątki odnoszące się do prób przerzutu obywateli państw (przede wszystkim) Azji czy Afryki na terytorium Unii Europejskiej, wszak to właśnie w okolicy Wołosatego w 2007 roku znaleziono Czeczenkę, której trzy córki nielegalną przeprawę do Polski przypłaciły życiem. Z kolei o ważnej drodze Lwów - Użhorod, na pewnym odcinku przebiegającej w bezpośrednim sąsiedztwie granicy z RP, tak oto pisał niedawno autor jednej z nielicznych polskich książek poświęconych Zakarpaciu: „Nie należy podróżować nią nocą - i to nie tylko dlatego, że jest nieoświetlona, biegnie przez pustkowia i pełno w niej dziur. Po prostu nocą można się tam natknąć na osoby, których lepiej nie spotykać w ciemnościach, zdolne zatarasować drogę czymkolwiek, by zatrzymać samochód. $Z$ ich powodu nawet w biały dzień lepiej się nie zatrzymywać, broń Boże, nie robić sobie postoju ani nie biwakować. Choć oficjalnie się o tym nie mówi, to tu, przez pogranicze obwodów lwowskiego i zakarpackiego, biegną szlaki ukraińskiej mafii, zajmującej się przemytem ludzi, narkotyków i Bóg wie jeszcze czego. Tędy też usiłują przedostać się na Zachód uciekinierzy z ukraińskich więzień i kolonii karnych” [Koprowski 2014: 12]. Wreszcie, to właśnie między innymi na tym odcinku pogranicza kręcono niektóre sceny kryminalno-sensacyjnego serialu telewizyjnego Wataha (2014 rok), w którym wątek przemytu również odgrywał ważną rolę, a także utrzymanego w podobnej konwencji filmu $\mathrm{Na}$ granicy $(2016)^{4}$. Opinię, że w Polsce nie mówi

Gwoli ścisłości należy zauważyć, że w tym ostatnim przypadku akcja filmu rozgrywa się na lwowskim, nie zaś zakarpackim, odcinku granicy polsko-ukraińskiej, choć szczegół ten - jak można przypuszczać - umyka uwadze przeciętnego odbiorcy tego obrazu. Tym zaś, co ma szansę pozostać w wyobraźni widza na dłużej, jest scena z przewróconym samochodem wypełnionym imigrantami ( $w$ większości martwymi) o azjatyckich rysach, w połączeniu z różnymi odcieniami służby bieszczadzkich funkcjonariuszy straży granicznej. 
się zbyt wiele o obwodzie zakarpackim, potwierdza też kilkunastodniowe milczenie, jakie w rodzimych mediach głównego nurtu zapanowało w lipcu 2015 roku wokół strzelaniny (z ofiarami śmiertelnymi), do której doszło na tle polityczno-mafijnym (wspomina się tu o rywalizacji o sprawowanie kontroli nad przemytem) w drugim największym mieście obwodu - Mukaczewie. Co ważne, mowa tu o zdarzeniu dość niezwykłym, spektakularnym i medialnym, które na dodatek rozegrało się w sąsiednim kraju, ledwie 60 kilometrów od granicy Polski.

Podsumowując tę część wypowiedzi, można więc powiedzieć, że brak związków historycznych, względne ubóstwo urbanistyczne i infrastrukturalne tej części Zakarpacia, krótka i trudno dostępna granica, brak punktu odpraw, stosunkowo małe znaczenie tego regionu dla Rzeczpospolitej, jak również w przeważającej mierze bezludny charakter polskiej części rzeczonego pogranicza - przyczyniają się do tego, iż nawet w kręgach specjalistów sąsiedztwu „polsko-zakarpackiemu” nadaje się stosunkowo niską rangę.

\section{Kontakty między Wołosatem a Łubnią}

Osobliwości zakarpackiego odcinka pogranicza ukraińsko-polskiego w sposób szczególny ujawniają się na przykładzie Łubni - liczącej około stu mieszkańców wsi, położonej na końcu jednej z bocznych dolin podchodzących pod Przełęcz Beskid. Siodło to, przez które przebiega granica polsko-ukraińska, stanowi wyraźne obniżenie w głównym grzbiecie Karpat. Po jego północnej stronie znajduje się polska osada Wołosate, która od wspomnianej przełęczy oddalona jest - podobnie jak Łubnia - o niespełna trzy kilometry. Przez setki lat owo bieszczadzkie pasmo rozdzielało ziemie polskie i węgierskie, choć nie brakowało również okresów, gdy tereny po jego obu stronach wchodziły w skład innych państw. W kontekście Zakarpacia wspomniano już o złożonej strukturze etnicznej miejscowej ludności; jeśli zaś chodzi o stronę polską, to - jak przypomina Leszek Rymarowicz [2012: 127] - choć według spisu ludności z 1921 roku w szeregu okolicznych wsi narodowość polską wskazywał znaczący (a na przykład w Wołosatem - nawet większościowy) odsetek pytanych, to jednak zasadniczo tę część ziemi sanockiej zamieszkiwała ludność wyznania greckokatolickiego i mówiąca po rusińsku.

Mieszkańcy Wołosatego tradycyjnie utrzymywali żywe kontakty z sąsiadami zza Przełęczy Beskid. Jak pisze Wojciech Krukar, dociekliwy badacz tych ziem, do utworzenia granicy z Czechosłowacją (po I wojnie światowej), 
kiedy to ograniczeniu uległy kontakty z miejscowościami po południowej stronie Karpat, częste były tu małżeństwa mieszane; co więcej, według niektórych opracowań, dopiero wtedy wzrosła liczba związków zawieranych z mieszkańcami sąsiednich polskich wiosek. Cytowany autor pisze również, że lektura prac naukowych, w których szczegółowo omówiono historię Wołosatego, zostawia czytelnika $\mathrm{z}$ wrażeniem, iż „względnie słabo poznana jest najnowsza historia wsi, od I wojny światowej po czas wysiedleń w połowie lat czterdziestych". W 1946 roku - pisał W. Krukar przed piętnastoma laty ludność Wołosatego „prawie w całości została przesiedlona [...] na Ukrainę i niewiele do dziś wiadomo o jej rozsiedleniu" [Krukar 2000: 36, 39-40] . $^{5}$ W innym miejscu można natomiast spotkać się z informacją, że mieszkańcy wsi „Z własnej inicjatywy (!) przeszli wraz z dobytkiem przez przełęcz Beskid na ukraińskie Zakarpacie. Podobno koczowali tam przez kilka tygodni pod gołym niebem, zanim władze zdecydowały, co z nimi począć" [Bieszczady... 2002: 383; zob. także Rymarowicz 2014: 116-117].

W latach siedemdziesiątych ubiegłego stulecia pojawił się pomysł utworzenia na wspomnianym obniżeniu drogowego przejścia granicznego, które miało odciążyć punkt graniczny w Medyce [Bieszczady... 2002: $224,373]$. Ostatecznie projekt ten nie doczekał się realizacji, jednak na rzecz tezy, że z przedsięwzięciem tym wiązano poważne plany, może świadczyć solidna konstrukcja mostu na drodze podchodzącej pod przełęcz. Mówiąc o niewykorzystanych szansach na udrożnienie omawianego odcinka granicy, warto cofnąc się do przełomu XIX/XX wieku, kiedy to, pomimo zaciekłych sporów, przez wspomniane obniżenie w grzbiecie nie udało się poprowadzić strategicznej linii kolejowej łączącej Budapeszt i Lwów [Rymarowicz 2012: 127], (omawiany fragment pogranicza był wtedy częścią tego samego państwa - Austro-Węgier). „Kto wie - zastanawiał się jednak w tym kontekście Wojciech Krukar [2014: 217] - czy gdyby kolej ze Lwowa na Zakarpacie poprowadzono przez Lutowiska i Wołosate, to dzisiaj miejscowości te nie byłyby poza granicami Polski”.

Przez kolejne dekady drugiej połowy XX wieku obie wsie (polska - niemal całkowicie opustoszała) pozostawały rozdzielone nieprzepuszczalną

W owym czasie autor ten dodawał, że bardzo dużą trudność sprawiało odnalezienie osób żyjących niegdyś w tej wsi, dzięki czemu łatwiej byłoby usunąć wspomniane białe plamy. Tym większą wartość ma więc fakt, że pół wieku po opuszczeniu Wołosatego przez jego mieszkańców wspomnianemu badaczowi udało się odnaleźć niektórych z nich w okolicach Stryja [Krukar 2000: 36-44], a także opisać ich wspomnienia i współczesne wysiłki na rzecz odwiedzin ich dawnej wsi rodzinnej - Wołosatego [Krukar 2014: 203-222]. 
granicą polsko-radziecką. Jak pisze W. Krukar [2014: 211], w tym czasie „jedynym źródłem informacji o Wołosatem dla jego dawnych mieszkańców były relacje osób, którym udało się dotrzeć z Łubni na przełęcz Beskid”. Jeśli chodzi o ruch ludności na szerszą skalę, pewien przełom nastąpił w pierwszych latach bieżącego stulecia, kiedy to staraniem pani wójt Wołosatego okazjonalnie, w ramach „Dni Dobrosąsiedztwa Wołosate - Łubnia”, na przełęczy kilkakrotnie otwierano granicę, umożliwiając mieszkańcom nawiązanie kontaktów i wspólną zabawę. Impreza ta nie jest już jednak kontynuowana - po raz ostatni, zresztą nie bez problemów organizacyjnych, miała miejsce w 2005 roku. W Wołosatem, a także w dyrekcji Bieszczadzkiego Parku Narodowego (BdPN), nie brakuje głosów, że spotkania te były pożyteczne ${ }^{6}$, co nie zmienia faktu, iż wraz ze śmiercią pani wójt - spiritus movens całego przedsięwzięcia - zaprzestano ich organizacji. W tym miejscu warto więc wspomnieć, że bogaty i różnorodny program Europejskich Dni Dobrosąsiedztwa, odbywających się od kilku lat w Zbereżach (powiat włodawski), a także analogiczna impreza w Kryłowie (powiat hrubieszowski) ${ }^{7}$, uzmysławiają, jak wiele tracą miejscowości pogranicza polsko-ukraińskiego pozbawione takich spotkań - organizowanych również tam, gdzie na stałe nie funkcjonuje przejście graniczne, a nawet, jak w przypadku wspomnianych miejscowości, gdy na Bugu należy w tym celu rozłożyć most pontonowy.

Pokłosiem wspomnianych ruchów ludnościowych z 1946 roku jest to, że również współcześnie na Zakarpaciu można spotkać osoby wspominające swych przodków, którzy przed siedemdziesięciu laty opuścili polską osadę. Dla przykładu warto tu przywołać mężczyznę z jednej z okolicznych wsi - Zahorbia, który stwierdził, że z Wołosatego pochodziła jego babcia, w związku z czym chętnie zobaczyłby dawną wieś rodzinną. O takich odwiedzinach marzył także każdy z odnalezionych przez W. Krukara [2014: 221] dawnych mieszkańców tej miejscowości. „W całym okresie powojennym organizowano wyjazdy na przełęcz Beskid. Wyjście na grzbiet Karpat połączone $\mathrm{z}$ oglądaniem rodzinnej doliny odbywało się 2 sierpnia, $\mathrm{w}$ dniu odpustu w Łubni. Po zejściu z przełęczy wszyscy bawili się na festynie, w «jakże bliskiej Wołosatego wsi». W lipcu 2009 roku próbowano uzyskać

Opinia dyrektora wyrażona podczas wywiadu przeprowadzonego przez autora w Ustrzykach Górnych w lipcu 2014 roku. Z tego samego okresu pochodzą przywoływane poniżej wypowiedzi sołtysa Ustrzyk Górnych, a także mieszkańców Wołosatego, które wchodzi w skład tego sołectwa.

Zob. http://fkdp.pl/wp-content/uploads/2014/07/EDD-2014.pdf, [14.04.2015]; http://krylow.info/ europejskie_dni-dobrosasiedztwa2015.html, [07.09.2015] 
zgodę polskiej strony na przejście $\mathrm{w}$ tym dniu $\mathrm{z}$ przełęczy Beskid do cmentarza w Wołosatem. (...) Niestety, władze takiej zgody nie wydały. Po raz pierwszy dawni mieszkańcy odwiedzili swoją rodzinną wieś 1 grudnia 2009 r[oku]"s.

Jak wynika z powyższego opisu, jeśli chodzi o kontakty między oboma częściami pogranicza, kwestią kluczową jest to, że nie udało się ich połączyć przejściem granicznym na drodze biegnącej przez Przełęcz Beskid. Jak wspomniano, Zakarpacie nie jest spójne $\mathrm{z}$ resztą Ukrainy, jednak nie tylko z tej racji jego władze dążą do tego, aby mieć „własny” punkt odpraw do Polski, nie zaś korzystać z odległego, położonego w Smolnicy (obwód lwowski), lub z tranzytu przez Słowację. Zdaniem dyrektora BdPN, pomysłowi otwarcia przejścia powyżej Łubni sprzyjają też władze Użańskiego Parku Narodowego, z różnych źródeł wiadomo, że inicjatywę mocno wspierają również niektórzy ukraińscy deputowani, władze regionalne, środowiska biznesowe, ale także mafijne. Zasadniczy problem polega jednak na tym, że cały 33-kilometrowy odcinek tego pogranicza objęty jest ochroną w ramach Bieszczadzkiego Parku Narodowego, którego władze od lat są konsekwentnie i kategorycznie przeciwne realizacji rzeczonego pomysłu. Jak twierdzi dyrektor BdPN, jeśli chodzi o uprzystępnianie Zakarpacia, wyjątek możliwy jest jedynie dla takich lokalizacji, których otoczenie gwarantuje, że nie powstanie tam punkt odpraw drogowych, czyli dla szczytu Krzemieniec ${ }^{9}$, na którym zbiegają się granice Polski, Ukrainy i Słowacji, lub dla okolic Sianek [Dębicki 2015b: 159, 162-164].

Z pomysłem uruchomienia punktu odpraw powyżej Wołosatego i Łubni łączy się także dużo szerszy problem - wstrzemięźliwego stosunku władz Rzeczpospolitej do uprzystępniania granicy polsko-ukraińskiej. Jeśli chodzi o jej zakarpacki odcinek, cytowany już analityk OSW przecinającą Przełęcz Beskid drogę określił mianem „trzeciorzędnej”, co było ilustracją tezy o niewielkim znaczeniu rzeczonego obwodu dla Polski [Olszański 2013: 14]. Jak pokazano w innym miejscu, pomysłowi otwarcia przejścia Woło-

8 Cytowany autor powołuje się tu na informacje uzyskane w lipcu 2009 roku od jednej z przedwojennych mieszkanek Wołosatego.

9 Kulminacja ta zasługuje na uwagę także dlatego, że - jako „symbol karpatorusińskiej jedności” ponad granicami - od kilku lat jest miejscem spotkań Rusinów z różnych państw w ramach imprezy plenerowej „Krzemieniecki Festiwal”; zob. http://karpatnews.in.ua/news/68627-shostyi-kreminetsfest-bez-grantovykh-vohnestroiv-nad-holovamy-miliardy-zirok.htm, [20.09.2015]. Informację tę, a także wskazówki bibliograficzne, zawdzięczam Pani Profesor Ewie Michnie z Uniwersytetu Jagiellońskiego. 
sate-Łubnia przeciwna jest także Straż Graniczna, dla której wszelki wzrost ruchu turystycznego na tym obszarze - intensywnie przez nią patrolowany w związku z licznymi próbami nielegalnego przekroczenia granicy, a także przerzutu ludzi przez grupy zorganizowane - jest zjawiskiem niepożądanym. Wyrażane nieformalnie stanowisko przedstawicieli tej instytucji, nawet jeśli nie ma charakteru wiążącego dla decydentów na szczeblu centralnym, nie pozostaje bez wpływu na opinie innych aktorów społecznych, w tym mieszkańców Wołosatego, którzy zresztą, sami z siebie, mają w kwestii uruchomienia przejścia odczucia co najwyżej ambiwalentne. Nie dość stanowczo i wyraźnie artykułowane jest w tej sprawie stanowisko turystów, których część popiera rzeczoną ideę, przy czym w ramach tego samego środowiska nie brakuje także osób niechętnych takiej formie uprzystępniania Przełęczy Beskid. Sprzeciw w tej materii wyrażają również kręgi ekologów [Dębicki, $\mathrm{w}$ druku].

W związku z powyższym zasadne są pytania o realizację polskiej racji stanu, której częścią jest poszerzanie pola kontaktów między Polakami a Ukraińcami. Warunkiem koniecznym, choć niewystarczającym, jest tu jednak udrażnianie granicy oraz ograniczanie dystansu dzielącego poszczególne miejscowości od punktów odpraw, do czego dodatkowym impulsem mogą być walory turystyczne obu części Bieszczad, a szczególnie - mało znanej wśród Polaków strony zakarpackiej. Warto dodać, że brak przejść na omawianym fragmencie pogranicza oznacza niemożność skorzystania przez Ukraińców z dobrodziejstw umowy o małym ruchu granicznym, na wprowadzeniu której zależało także stronie polskiej.

\section{Granica jako bariera oswojona i niewidzialny mur}

Przyjmując perspektywę socjologii pogranicza - dziedziny zorientowanej między innymi na interakcje pomiędzy społecznościami z obu stron granicy państwowej, szczególnie te realizowane na płaszczyźnie lokalnej - podczas rozmów z mieszkańcami wsi doliny górnego Użu dostrzegamy pewną zasadniczą kwestię. Ludzie ci - między innymi owe kilkanaście osób, z którymi prowadzono rozmowy - chociaż żyją w odległości ledwie kilku kilometrów od granicy z Polską, sąsiedztwa tego doświadczają w stopniu co najwyżej minimalnym, dla wielu zaś osób jest to kwestia mocno abstrakcyjna. Jak wspomniano, Łubnia i Wołosate są od siebie oddalone o niespełna sześć kilometrów, jednak najkrótszy dystans, który należy pokonać, aby z jednej wsi dostać się legalnie do drugiej, 
czyli przez przejście drogowe Krościenko - Smolnica, to prawie dwieście kilometrów ${ }^{10}$.

„Położenie geograficzne [Zakarpacia - dop. M.D.] oraz 19 przejść granicznych powodują, że kontakty mieszkańców regionu z UE są częstsze niż statystycznego obywatela Ukrainy" - piszą analitycy OSW [Żochowski, Iwański 2015: 2], jednak prawidłowość ta raczej nie odnosi się do Polski. W obliczu braku przejścia na Przełęczy Beskid kwestię kluczową dla interakcji „polsko-zakarpackich” stanowi fakt, że mowa tu o „jednym z biedniejszych regionów Ukrainy. Średnia pensja w okresie styczeń-maj [2015 roku] w obwodzie wynosiła niecałe 3 tys. hrywien (ok. 130 USD), o połowę mniej niż w Kijowie" [Żochowski, Iwański 2015: 1-2]. Ludzie tu do Polski nie jeżdża, bo ich na to nie stać - potwierdza drobny przedsiębiorca z Wołosianki, mając na myśli mieszkańcow tej miejscowości oraz sąsiedniego Użoka (choć warto dodać, że ubóstwo to przekłada się na ograniczenie mobilności tych ludzi również w wymiarze lokalnym czy regionalnym). Kategoryczne stanowisko zajmuje także wyższy rangą funkcjonariusz Straży Granicznej w Werchowynie-Bystrej, a więc wsi, której bliskość położenia wobec granicy z Polską oznacza jednocześnie peryferyjność w skali obwodu czy choćby rejonu: to biedaki, na chuj im tam [do Polski] jechać? Jak się wydaje, styl wypowiedzi wskazuje, że jej autor nie spodziewał się tu przekonującej riposty.

Pomijając posterunki na Przełęczy Użockiej, oddzielającej obwód zakarpacki i lwowski, oraz we wsi Użok - w okolicznych wsiach, a także przy samej granicy z Polską, w mniejszym stopniu niż w nieodległym Wołosatem odczuwa się obecność funkcjonariuszy straży granicznej. Z faktu, że po stronie ukraińskiej stosowne służby „nie narzucają się” ze swą obecnością, korzystają miejscowi - przede wszystkim mieszkańcy Łubni i Werchowyny-Bystrej, które leżą stosunkowo blisko granicy państwa, a jednocześnie w sąsiedztwie terenów atrakcyjnych pod wypas bydła lub zbiór grzybów czy owoców - niejednokrotnie przekraczając w tym celu granicę z Rzeczpospolitą. W takich właśnie okolicznościach, wysoko na połoninach, niekiedy „zapuszczają się" oni na głębokość kilku-kilkunastu metrów na terytorium Polski, przy czym stosunkowo częste występowanie tego procederu sugeruje, że osoby te albo nie całkiem rozumieją, iż naruszają granicę z Unią

10 Opisywany przypadek przywodzi na myśl realia sprzed 1989 roku, kiedy to mieszkańcy północnej Polski, aby odwiedzić nieodległy Kaliningrad, musieliby - pomijając trudności formalne - jechać setki kilometrów, przez Białoruś i Litwę, gdyż najbliższy punkt odpraw między Polską a ZSRR znajdował się w Brześciu [Kurcz 2012: 474]. 
Europejską, albo zwyczajnie rygor ten lekceważą ${ }^{11}$. Ludzie tam czasami chodza, bo po polskiej stronie są lepsze jagody. Jak kogoś złapia [polscy - dop. M.D.] pogranicznicy, to za pierwszym razem jest ostrzeżenie, ale za drugim już mandat - śmieje się mieszkanka Werchowyny-Bystrej. Rozprężenie w kwestii granicy - zachowanie typowe dla wielu społeczności żyjących w jej pobliżu - czasami próbuje się przenieść także na przybyszów z Polski, oferując im własne przewodnictwo w dotarciu pod kordon, przy świadomości, że ma się do czynienia z obcokrajowcami, a nieopodal granicy znajduje się grodzący dojście do niej szlaban: e tam, granica, no i co, że granica? - prowokował jeden z mieszkańców Łubni, w odpowiedzi na obawy przybyłego do wsi turysty, zainteresowanego dotarciem do Przełęczy Beskid.

Chociaż także w czasach radzieckich zdarzało się, że ktoś z miejscowych zbliżył się do granicy, a nawet ją przekroczył, to jednak odwołanie do ówczesnych realiów [Potaczała 2015: 20] pozwala dostrzec, jak wiele zmieniło się w rzeczonej materii. Dziś bowiem, jak się wydaje, do wyobraźni miejscowych, bardziej niż obecność polskich bądź ukraińskich służb, przemawiają opowieści patrolujących ten teren pograniczników o zorganizowanych grupach próbujących przedrzeć się na Zachód lub indywidualne doświadczenia społeczności lokalnych $\mathrm{z}$ uczestnikami takich przerzutów.

Bez względu na przyczyny omawianego stanu rzeczy, dezynwoltura, z jaką okoliczna ludność traktuje pilnie strzeżoną unijną granicę, sugeruje, że mamy tu do czynienia ze (świadomą lub nie) próbą zdjęcia $z$ owej linii otoczki nadanej jej wraz z przystąpieniem Polski do Unii Europejskiej i strefy Schengen. Jest to więc sytuacja zupełnie odmienna od tej, z jaką spotykamy się w Wołosatem, gdzie turystów instruuje się, niekiedy nawet z pewną dozą egzaltacji, że nieopodal wsi przebiega pilnie strzeżona granica z Ukrainą, więc lepiej się tam nie zbliżać. Zarazem jednak można powiedzieć, że nieodległy kordon, pomimo braku punktu odpraw, w pewnym sensie istnieje w świadomości mieszkańców okolicznych zakarpackich wsi, którzy - inaczej niż to ma miejsce zwykle - potrafią zrekonstruować obraz owej linii demarkacyjnej, to, „co się na niej dzieje” [Kurczewska 2003: 38]. Jest to jednak efekt „tradycyjnego" (rolniczego) stylu życia danej społeczności i takiegoż pojmowania funkcji granicy, która jest tu jak gdyby częścią lokalnego środowiska przyrodniczego, być może także swoistą, zdecydowanie

11 Tego typu zdarzenia musiały być dość liczne, skoro skłoniły polską straż graniczną do wystosowania apelu do mieszkańców zakarpackich wsi, w którym informowano o konsekwencjach, jakie będą wyciągane wobec osób ujętych na przekroczeniu „zielonej granicy”. 
oswojoną, ciekawostką tudzież atrakcją krajoznawczą, nie zaś - zjawiskiem politycznym.

Jeśli chodzi o wpływ, jaki brak punktu odpraw na Przełęczy Beskid ma na kształt życia mieszkańców zakarpackich wsi zlokalizowanych niedaleko granicy z Polską, można wspomnieć o kilku sferach. Chodzi tu więc zarówno o pozbawienie tych społeczności możliwości zarobku stwarzanych przez handel przygraniczny, o ich społeczną (transgraniczną) izolację, pozostawienie na uboczu procesów cywilizacyjnych, jak i zjawiska związane $\mathrm{z}$ przemianami w krajobrazie kulturowym i przyrodniczym. Jeszcze inną konsekwencją braku łączności z Wołosatem jest fakt, że wiedza pewnej części mieszkańców okolicznych zakarpackich wsi na temat sąsiada zza bieszczadzkiego grzbietu często nie sięga nawet tak typowych dla pogranicza sfer życia jak ceny podstawowych artykułów spożywczych (podczas rozmowy w Łubni pytano na przykład: no, a ile u was kosztuje chleb albo masło, albo piwo?), wysokość zarobków czy kursy walut, a więc kwestie, które zwykle stanowią elementarny zasób wiedzy społeczności żyjących przy granicy państwa. Nie jest też niczym szczególnym, że pojawiających się niekiedy $\mathrm{w}$ okolicy turystów z Polski, rozpoznając w ich mowie pewne powinowactwo do swojej, identyfikuje się przede wszystkim ze Słowakami lub Czechami.

Jednocześnie to właśnie przybysze z Polski stanowią dla miejscowych pewne źródło informacji o tym państwie, przy czym warto pamiętać, że interakcje te ze swej natury są okazjonalne, przesiąknięte asymetrią potencjałów, dodatkowo wzmocnioną rolą, w jakiej występują przedstawiciele obu nacji (biedni ukraińscy gospodarze versus względnie bogaci polscy turyści), nietrwałe i oderwane od tego, co jest lub mogłoby być wspólne dla mieszkańców osad z obu stron granicy. Jak bowiem wiadomo, to nie klasyczna turystyka decyduje o charakterze kontaktów na transgraniczu polsko-ukraińskim [Konieczna-Sałamatin 2012: 18-21], lecz handel i przemyt. To dlatego wspomniany wcześniej brak zainteresowania mieszkańców Wołosatego uruchomieniem przejścia wypada ujmować w kontekście uwag sformułowanych przez Zbigniewa Kurcza, dla którego jednym z obszarów koncentracji socjologii pogranicza winna być analiza ruchu granicznego. Co ważne, znaczenie ma tu między innymi deklarowany cel podróży przez granicę, gdyż wzrost liczby wizyt typu odwiedziny przy spadku odsetka osób, które odwiedzają sąsiada w celach turystycznych lub handlowych, pozwala "domniemywać, że krzepnie pogranicze w socjologicznym rozumieniu" [Kurcz 2010: 297-298]. Przy tym wszystkim warto dodać, że wspomniana wyżej nieznajomość (i po stronie 
polskiej, i ukraińskiej) może zarazem leżeć u podstaw wrażenia, że tych nielicznych Polaków, którzy decydują się odwiedzić Zakarpacie, obdarza się tu życzliwością (a przynajmniej „życzliwą ciekawością”), na co - jak wspomniano - pewien wpływ ma także postawa, jaką Polska zajęła w obliczu wojny w Donbasie.

Jak starano się pokazać, rzeczony brak rozeznania w polskiej rzeczywistości jest konsekwencją wspomnianego odcięcia omawianego obwodu od miejscowości po drugiej stronie granicy, w związku z czym ewentualne interakcje transgraniczne wymagałyby sporego nakładu inwestycyjnego. W praktyce są one jednak rzadkością, wszak kluczową kwestią jest tu ubóstwo mieszkańców zakarpackich wsi, choć ważną rolę odgrywa także brak związków historycznych, ponieważ Zakarpacie - w przeciwieństwie do Wołynia, Galicji Wschodniej czy ziem położonych jeszcze bardziej na wschód Ukrainy - nigdy nie było częścią Rzeczpospolitej. Okoliczności te skutkują tym, że miejscowa ludność za pracą chętniej niż do Polski wyjeżdża do Czech, na Słowację czy Węgry, polscy turyści natomiast dość sporadycznie odwiedzają rzeczony region, preferując pasma górskie i miejscowości, które wchodziły w skład I lub II RP. Odwołując się do pism Stanisława Ossowskiego [1984: 35], należy też zauważyć, że mieszkańcy Łubni nie sięgają wzrokiem obszaru, na którym rozłożyło się Wołosate - ani $\mathrm{z}$ „kościelnej dzwonnicy”, która we wsi znajduje się w cerkwi, ani z „wyniosłego akropolu", którego funkcję mogłaby tu pełnić Przełęcz Beskid [Dębicki 2015a: 148].

\section{W oczekiwaniu na otwarcie przejścia}

Chociaż obecnie nie ma perspektyw dla uruchomienia przejścia granicznego na Przełęczy Beskid, to jednak opinie niektórych osób indagowanych $\mathrm{w}$ tej sprawie na Zakarpaciu sugerują co innego. Uwagę zwraca bowiem artykułowane przez część $\mathrm{z}$ nich przekonanie, że - zgodnie z obietnicą złożoną przez władze - punkt odpraw miał zostać otwarty już w sierpniu 2014 roku, tyle że plany te pokrzyżowała agresja Rosji na Ukrainę. W tym kontekście warto wspomnieć o spotykanych w Łubni domach wystawionych na sprzedaż, przy czym - jak stwierdził sołtys Ustrzyk Górnych - obecnie sfinalizowanie transakcji nie jest możliwe, ponieważ właściciele tych obiektów czekają, aż zostanie otwarte przejście, wraz z którym miałaby wzrosnąć wartość nieruchomości. Dyrektor BdPN dodawał zaś, że w okolicy wykupiono już działki pod inwestycje właśnie z myślą o udrożnieniu nieodległej granicy. 
Jak wspomniano, na Ukrainie pomysł uruchomienia przejścia na Przełęczy Beskid cieszy się stosunkowo dużą akceptacją. Gdyby powstało to przejście tam na Łubni, to byłoby to dobre dla turystyki - stwierdził jeden $\mathrm{z}$ okolicznych drobnych przedsiębiorców. Również zakarpackie media ${ }^{12}$ w ostatnich latach parokrotnie informowały o dwustronnych spotkaniach różnego szczebla ( $w$ tym $\mathrm{z}$ udziałem kręgów dyplomatycznych), podczas których stale powracającym tematem jest postulat otwarcia przejścia na przełęczy. Optując za tym rozwiązaniem, wskazuje się, że po obu stronach granicy istnieje droga, która mogłaby służyć pieszym i rowerzystom, co oznacza zmniejszenie nakładów finansowych niezbędnych do uruchomienia przejścia; akcentuje się zainteresowanie tą inicjatywą ze strony mieszkańców Zakarpacia, którzy w obecnych warunkach, pragnąc odwiedzić Polskę, zmuszeni są poważnie nadkładać drogi; podnosi się również potrzebę intensyfikacji współpracy transgranicznej na poziomie regionalnym (obwodowym). Przy tym wszystkim uwagę zwraca sposób formułowania komunikatów, wszak z niektórych z nich wynika, że do otwarcia przejścia wiele już nie trzeba (co może tłumaczyć optymizm prezentowany w tym względzie przez część społeczności lokalnych). Dla przykładu, jedną z relacji medialnych (z kwietnia 2013 roku) opatrzono nagłówkiem: „Polski ambasador dał zielone światło dla nowego przejścia granicznego na Zakarpaciu” (chodziło o słowa Ambasadora RP w Kijowie Henryka Litwina), inną zaś hasłem: „W Karpatach będzie nowe przejście graniczne z Polską"; w podobnym tonie zwracano się do swych czytelników także na początku 2015 roku $^{13}$. Jednocześnie, jak wynika z relacji z owych spotkań, w rozmowach raczej nie pojawia się Bieszczadzki Park Narodowy, a więc główny przeciwnik pomysłu. W związku z powyższym można przyjąć, że jeśli chodzi o nastawienie wobec dyskutowanej inicjatywy, przypadek Łubni pozostaje w zbieżności z tendencją obecną na innych odcinkach wspólnego pogranicza, w myśl której przejściem granicznym w większym stopniu niż

12 Poniższa relacja powstała w oparciu o przegląd następujących wybranych serwisów informacyjnych z Zakarpacia: http://trubyna.org.ua/novyny/polyaky-poobitsyaly-vidkryty-punkt-perehodu-nakordoni-iz-zakarpattyam, (9.05.2015); http://chas-z.com.ua/news/13874, [9.05.2015]; http://panoramamukachevo.com/2014/04/24/85170, [09.05.2015]; http://ua-reporter.com/taxnonomy/term/20138, [09.05.2015]; http://112.ua/obshchestvo/v-zakarpatskoy-oblma-polsko-ukrainskoy-granice-postiyat-peshehodnyy-perehod-hubnya-volosatoe-180661.html, [9.05.2015]; http://tsn.ua/ukrayina/uzakar-patskomu-seli-lubnya-nemaye-pershoklasnikiv.htmal, [09.05.2015]. Za pomoc w dotarciu do tych źródeł dziękuję magistrowi Andrijowi Yurkevychowi z Teatru Álter w Drohobyczu.

13 Nagłówki za: http://ua-reporter.com/taxnonomy/term/20138, [09.05.2015]. Przejście w Łubni zaznaczona także na mapie obwodu wiszącej na jednej ze ścian dziedzińca zamku w Mukaczewie. 
Polacy zainteresowani są Ukraińcy, którzy częściej kojarzą je z korzyściami [Świdrowska 2012: 65-66, 72].

Warto zaznaczyć, że gdyby pomysł otwarcia przejścia na Przełęczy Beskid doczekał się realizacji, wówczas znacząco zmieniłby się krajobraz przyrodniczy i kulturowy okolicznych wsi, przede wszystkim Łubni - i to niezależnie od faktu, iż miejscowości te wchodzą w skład Użańskiego Parku Narodowego, ponieważ na Ukrainie tego typu instytucje funkcjonują opierając się na reżimie ochronnym dużo łagodniejszym niż w Polsce. Obecnie o tym, że we wspomnianej osadzie nie ma przejścia granicznego, świadczy miejscowa estetyka i typ zagospodarowania przestrzennego. Nie uświadczy się tu - typowych dla miejscowości, w których funkcjonuje przejście - materialnych dowodów na twierdzenie, że „Z granicy można żyć”, jak sklepy (jest jeden), gastronomia, schludniejsze i bardziej okazałe domostwa czy obiekty noclegowe, dzięki czemu wzrastałaby ocena wizualnego odbioru miejscowości. Wręcz przeciwnie - sporo spośród okolicznych wsi charakteryzuje się daleko posuniętą degradacją kultury materialnej oraz marginalizacją społeczną części mieszkańców. Tak też jest dziś z samą Łubnią - miejscowością dość ubogą, w której już krótki pobyt ujawnia niekompatybilność pomiędzy zasobami mieszkańców a niekiedy artykułowanym przez nich popytem na oferowane w lokalnym sklepie produkty, takie jak tytoń czy alkohol. Być może więc właśnie jako taką - położoną na uboczu szlaków komunikacyjnych, wciśniętą gdzieś „za górami, za lasami” czy „na końcu świata”, pod nieprzepuszczalną granicą - zapamiętali tę osadę mieszkańcy Wołosatego, którzy przed laty zdecydowali się ją odwiedzić. Jak wspomniano, turystom zainteresowanym wejściem na graniczną Przełęcz Beskid oferuje się tu asystę, w innych zaś sytuacjach - nocleg czy transport. I chociaż niekoniecznie wspomina się przy tym o zapłacie, co skłania do traktowania tej oferty jako przejawu gościnności, to jednak - gdyby uwzględnić stanowisko jednego z mieszkańców Wołosatego - propozycję tę można by widzieć także jako przykład motywowanego chęcią zarobku nagabywania, które wraz $\mathrm{z}$ otwarciem przejścia miałoby pojawić się także po stronie polskiej.

Należy założyć, że tego typu aktywność Ukraińców, w połączeniu z możliwością poznania przez sąsiadów zza nieodległego grzbietu lokalnego stylu i poziomu życia, w krótkim czasie przyczyniłaby się do ukształtowania wśród nich (w niektórych przypadkach - jedynie wzmocnienia) określonego obrazu Zakarpacia. Otwarcie przejścia powyżej Łubni - jedynego na omawianym pograniczu, zlokalizowanego na obszarze stosunkowo 
atrakcyjnym turystycznie i dostępnego dla niezmotoryzowanych - oraz uprzystępnienie obwodu na szerszą skalę osobom, które odtąd miałyby możliwość odwiedzenia Ukrainy „przy okazji” pobytu w rodzimej części Bieszczad, prawdopodobnie pociągnęłoby za sobą także szereg konsekwencji innego rodzaju. Może tu chodzić o upowszechnienie wśród gości z Polski postkolonialnego podejścia do Ukrainy, praktykowanego podczas wędrówek po innych jej częściach [Cobel-Tokarska 2015], czy o utratę przez okoliczne wsie swoistej autentyczności - choćby tej na miarę postradzieckich lokalizacji pozbawionych rozbudowanej infrastruktury turystycznej [Horolets 2012: 125]. Mówiąc o społeczno-kulturowym wymiarze zmian spowodowanych uruchomieniem przejścia, wypada wspomnieć również o typie świadomości mieszkańców północnego Zakarpacia, w której zapewne także pojawiłyby się elementy myślenia w kategoriach transgranicznych, jak również wiedza czy stereotypy na temat drugiej strony. Jako że - jak wspomniano - inwestycji na Przełęczy Beskid mogą towarzyszyć zmiany stosunków własnościowych w Łubni i otoczeniu, warto wskazać na przypadek innej niewielkiej zakarpackiej wsi - Malich Slemencich, położonej na granicy ze Słowacją. Odkąd w 2005 roku uruchomiono tam przejście dla pieszych i rowerzystów, w miejscowości zaobserwowano znaczące zmiany. Jak pisze Jessica Allina-Pisano, w związku z otwarciem punktu odpraw wyremontowano drogę dojazdową do wsi, niektórzy jej mieszkańcy czerpią zyski z wynajmu powierzchni osobom trudniącym się handlem, jednocześnie jednak społeczność lokalna ponosi krajobrazowo-estetyczne koszty przedsięwzięcia. Sami jej przedstawiciele zwracali uwagę na fakt, że brud, harmider, wzmożony ruch czy zmiana funkcji niektórych obiektów zaburzyły rolniczy charakter osady, która dotychczas znajdowała się "na końcu świata”. Jako że miejscowych nie było stać na uruchomienie własnych biznesów, a także nie mieli oni umocowania we władzach obwodu, zasadnicze zyski generowane przez ruch na przejściu trafiają do kieszeni osób spoza wsi lub jej nowo przybyłych mieszkańców (przede wszystkim z nieodległego Użhorodu - stolicy Zakarpacia). Wypada dodać, że te i inne ruchy ludnościowe zaingerowały również w etniczno-językową tożsamość Malich Slemencich [Allina-Pisano 2009: 274-284].

Warto zatem zaznaczyć, że rozwój infrastruktury i inne tempo oraz styl życia, które pojawiłyby się w Łubni i okolicznych wsiach wraz z otwarciem przejścia granicznego, $\mathrm{z}$ pewnością znacząco zaingerowałyby w szeroko rozumiany rytm funkcjonowania tych miejscowości. Podobnie rzecz miałaby 
się ze środowiskiem przyrodniczym, także zresztą po polskiej stronie granicy, czego tak bardzo - i zasadnie - obawiają się władze BdPN, dążąc do tego, aby rzeczony pomysł uczynić trwale niemożliwym do realizacji.

\section{W stronę refleksji teoretycznej. Podsumowanie}

Chociaż Łubnia i kilka innych wsi położone są w niewielkiej odległości od granicy z Polską, to jednak brak punktu odpraw powoduje, że linia ta wydaje się funkcjonować w świadomości okolicznej ludności głównie w kontekście obszaru, na którym można zaspokoić potrzeby gospodarstwa domowego (co skutkuje dość lekceważącym do niej stosunkiem), a także jako arena działalności przestępczej, nie zaś jako szczególnie znaczące zjawisko polityczne czy państwowe. Przedstawicielom społeczności północnego Zakarpacia trudno jest natomiast zrekonstruować - jak to ujmuje w innym kontekście, choć także zaczerpniętym z pogranicza polsko-ukraińskiego, Joanna Kurczewska [2003: 38] - wyobrażenia „bliskiego terytorialnie otoczenia społecznego i cywilizacyjnego". Do mieszkańców okolicznych wsi można więc odnieść również inną obserwację tej samej autorki - że ludność ta „nie przeżywa pogranicza”. Osoby te nie wiedzą, co się dzieje po drugiej stronie granicy, nikogo tam nie odwiedzają i „orientują się na siebie samych albo na kulturę i politykę w perspektywie własnych narodowych i państwowych centrów" [Kurczewska 2005: 373].

Nieprzepuszczalność granicy, odcięcie od społeczności z jej drugiej strony i nieznajomość tamtejszych realiów utrwalają izolację mieszkańców Łubni i innych osad względem swych sąsiadów z Wołosatego czy Ustrzyk Górnych, ale także - nieobecność Zakarpacia w świadomości Polaków. Sytuacja ta prowokuje do tego, aby sięgając do dorobku socjologii pogranicza stwierdzić, że na omawianym obszarze mamy do czynienia z pograniczem administracyjnym, które konstytuowane jest przez samo tylko istnienie granicy, nie zaś społecznym, tworzącym się za sprawą kontaktów między ludnością z obu jej stron [Kurcz 2012: 465]. Pomijając wspomnianą „aktywność transgraniczną" związaną ze zbieractwem oraz zorganizowane działania przemytnicze, raczej zresztą niebędące udziałem miejscowej ludności, należy stwierdzić w duchu zaproponowanym przez Andrzeja Sadowskiego [1996: 7], że miejscowości interesującego nas fragmentu pogranicza, choć od granicy dzieli je ledwie kilka kilometrów, żyją w rytmie i stylu całkowicie wolnym od kultury sąsiada, sam zaś kordon pełni tu wyłącznie funkcję delimitacyjną. 
Do omawianego przypadku można odnieść także dwa z trzech ujęć pogranicza autorstwa Grzegorza Babińskiego - perspektywę kresów oraz końca „naszego” i początku „innego” świata - które do pewnego stopnia są zresztą do siebie podobne. Jest w nich bowiem mowa o końcu „własnego świata społeczno-kulturowego, poza którym nie ma prawie nic "naszego» i z którym nie utrzymuje się szerszych kontaktów. Takie rozumienie ma charakter bardziej symboliczny niż dosłowny - wszak ten »nie nasz « świat istnieje i z reguły wiadomo o nim dosyć dużo. Ale jest to świat inny, obcy, czasami wrogi, na pewno nie równy "naszemu «". Ponadto, w perspektywie końca "naszego" i początku „innego" świata zakłada się, że pogranicze „bywa w świadomości bardziej granicą niż obszarem przejściowym, bardziej obszarem dzielącym niż łączącym" [Babiński 1997: 58-59]. Wprawdzie w przypadku Wołosatego i Łubni trudno jest mówić o wrogości, sam zaś powyższy model - szczególnie wątek „inności”, wynikający z przeświadczenia części mieszkańców polskiej strony o granicy jako o „końcu własnego świata" - można odnieść także do niejednego innego odcinka pogranicza polsko-ukraińskiego (i nie tylko tego), to jednak przypadek zakarpacki wydaje się być najbardziej barwną i wyrazistą ilustracją ujęcia G. Babińskiego. Z pewnością zaś tym, co wydaje się szczególnie pasować do kontekstu Wołosatego i Łubni (czy innych zakarpackich wsi), jest wzajemna o sobie niewiedza.

Chociaż opinie mieszkańców badanego fragmentu pogranicza ukraińsko-polskiego, przywoływane w artykule pośrednio lub wprost, zostały pozyskane według schematu próby opartej na dostępności badanych, to jednak wysoki poziom zbieżności owych odczuć, wyrażających się w całkowitym braku występowania „transgranicznych doświadczeń”, w połączeniu z obiektywnymi ograniczeniami terenowymi i administracyjnymi, pozwalają wysunąć hipotezę, że zakres obowiązywania formułowanych w artykule wniosków zdecydowanie wykracza poza osoby indagowane. Na poziomie konkluzji płynącej ze zrealizowanych w trzech turach kilkudniowych rozmów i obserwacji można zaś (sięgając do terminologii przyrodniczej) twierdzić, że rzeczywistość omawianego odcinka pogranicza przypomina stan endemizmu - $\mathrm{z}$ tą różnicą, iż chodzi tu nie o „rośliny lub zwierzęta (...) występujące na niewielkim, ograniczonym terytorium, tylko jemu właściwe" [Słownik... 1998: 509], lecz o ludzi. Wypada bowiem zauważyć, że mieszkańcy okolicznych wsi, żyjąc w cieniu nieodległej, ale nieprzepuszczalnej granicy, dostarczają badaczom relacji społecznych na pograniczach wyjątkowego, bo coraz rzadziej już spotykanego, materiału. Gdyby więc sformułowana powyżej hipoteza uzyskała szersze potwierdzenie empi- 
ryczne, można by przekonująco dowodzić, że w przypadku zakarpackiego fragmentu pogranicza ukraińsko-polskiego (a szczególnie Łubni) mamy do czynienia z czymś, co w dzisiejszym świecie wydaje się nieprawdopodobne: całkowitym odcięciem od siebie, w środku Europy, mieszkańców dwóch sąsiadujących ze sobą wsi.

Co więcej, trudno też zakładać, aby opisywana sytuacja w najbliższej przyszłości uległa zasadniczej zmianie. Chodzi przy tym nie tylko o wspomniany opór władz Bieszczadzkiego Parku Narodowego, ale także o przewidywania, że jednym z potencjalnych korytarzy migracyjnych dla uchodźców z Azji i Afryki może być Polska. Bieszczady - jedyny obszar górski na polskim odcinku zewnętrznej granicy UE, owiane sławą miejsca „tradycyjnie" wykorzystywanego do przerzutu ludzi - w przypadku rygorystycznych kontroli na granicach RP niewątpliwie stałyby się wówczas jeszcze bardziej atrakcyjne dla imigrantów, a przez to jeszcze pilniej strzeżone. Należy bowiem pamiętać, że kojarzony z otwarciem przejścia wzmożony ruch turystyczny, zarówno krajowy, jak i międzynarodowy, działania stosownych służb mógłby tylko utrudniać.

„Chociaż struktury państwa na międzynarodowych granicach są często statyczne, negocjowanie politycznych i ekonomicznych działań oraz wartości (...) między agendami i organami państwa, podróżnikami i tymi, którzy żyją na granicy, jest ciągłe i dynamiczne" - stwierdzają badacze pogranicz [Donnan, Hastings 2007: 24]. Odnosząc ten model do badanego obszaru, zauważamy jednak, że cechuje się on, również obecnie, występowaniem okoliczności służących utrwaleniu stanu, który został określony jako endemizm zakarpackiego odcinka pogranicza polsko-ukraińskiego. Chociaż bowiem dyskusja na temat uruchomienia przejścia granicznego Wołosate - Łubnia toczy się już od przynajmniej kilkunastu lat (co pozwala stwierdzić, że jest ona zjawiskiem ciągłym), to jednak trudno jest w niej odnaleźć dynamikę, wszak wydaje się, iż rzecz cała wciąż tkwi mniej więcej w tym samym miejscu, skutkiem czego Polska nadal jest jedynym spośród czterech państwowych sąsiadów Zakarpacia, z którym nie łączy go żadne przejście graniczne. Jest to jedna z przyczyn, dla których eksperci Ośrodka Studiów Wschodnich, stwierdzając, że unikalne przygraniczne położenie obwodu sprawia, iż „zjawisko kontrabandy - przede wszystkim papierosów, ludzi i narkotyków, a także drewna z nielegalnego wyrębu - przybiera coraz większe rozmiary", oraz wskazując na częstsze niż w przypadku statystycznego obywatela Ukrainy kontakty mieszkańców regionu z UE - w całej swej dziewięciostronicowej analizie współczesnych realiów Zakarpacia ani razu nie wspominają o Polsce [Żochowski, Iwański 2015: 2]. 


\section{Bibliografia}

Allina-Pisano J. (2009), From Iron Curtain to Golden Curtain. Remaking Identity in the European Union Borderlands, "East European Politics and Societies”, nr 2.

Babbie E. (2004), Badania społeczne w praktyce, przeł. W. Betkiewicz i in., Warszawa.

Babiński G. (1997), Pogranicze polsko-ukraińskie. Etniczność-zróżnicowanie religijne-tożsamość, Kraków.

Bieszczady. Przewodnik (2002) [praca zbiorowa] Pruszków.

Cobel-Tokarska M. (2015), „Strasznie i pięknie”. Ukrainskie podróże młodych Polaków, [w:] M. Dębicki, J. Makaro (red.), Sąsiedztwa III RP - Ukraina. Zagadnienia społeczne, Wrocław.

Dębicki M. (2015a), Wokół idei otwarcia przejścia granicznego na Ukrainę w bieszczadzkiej wsi Wołosate. Propozycja ram teoretycznych zagadnienia, [w:] P. Frączek, J. Karolczuk (red.), Na pograniczach. Szanse i zagrożenia społeczne, Sanok.

Dębicki M. (2015b), Wzdłuż meandrów Sanu. Transgraniczność nieobecna, nieoczywista, potencjalna, wyobrażona - jako refleks współczesnych i niegdysiejszych realiów bieszczadzkiego odcinka pogranicza polsko-ukraińskiego, [w:] M. Dębicki, J. Makaro (red.), Sąsiedztwa III RP - Ukraina. Zagadnienia społeczne, Wrocław.

Dębicki M. (w druku), Niedoszłe przejście graniczne Wołosate-Łubnia. Losy inicjatywy jako element refleksji nad bieszczadzkim odcinkiem pogranicza polsko-ukraińskiego.

Donnan H., Wilson T. M. (2007), Granice tożsamości, narodu, państwa, przeł. M. Głowacka-Grajper, Kraków.

Horolets A. (2012), Codzienność jako atrakcja turystyczna w doświadczeniu turystów niszowych do byłego ZSRR, „Kultura i Społeczeństwo”, nr 3.

Konieczna-Sałamatin J. (2012), Pogranicze polsko-ukraińskie jako niewykorzystana szansa, [w:] J. Fomina, J. Konieczna-Sałamatin (red.), Granica do naprawy. Problemy pogranicza Polski i Ukrainy, Warszawa.

Koprowski M. A. (2014), Inna Ukraina. Zakarpacie - tu się zaczyna i kończy Europa, Zakrzewo.

Krukar W. (2000), Gniazdo Tarnicy-Halicza i dolina Wołosatego. Materiały do monografii, „Płaj. Almanach Karpacki”, z. 20.

Krukar W. (2014), Wołosackie silva rerum, „Płaj. Almanach Karpacki”, z. 49.

Krzysztofek K. (2003), Co dalej z narodem?, „Pogranicze. Studia Społeczne”, t. 11.

Kurcz Z. (2010), Socjologia pogranicza i człowiek pogranicza w świetle polskich doświadczeń, [w:] Z. Kurcz, I. Taranowicz (red.), Okolice socjologicznej tożsamości. Księga poświęcona pamięci Wojciecha Sitka, Wrocław.

Kurcz Z. (2012), Powrót pograniczy. Entuzjazm, normalność, problemy, [w:] K. Frysztacki, P. Sztompka (red.), Polska początku XXI wieku: przemiany kulturowe i cywilizacyjne, Warszawa . 
Kurczewska J. (2003), Granica polsko-ukrainska: trzy spojrzenia teoretyczne, [w:] M. Zielińska (red.), Transgraniczność w perspektywie socjologicznej. Teorie, studia, interpretacje, t. 1, Zielona Góra.

Kurczewska J. (2005), Granica niejedno ma imię. Trzy podejścia teoretyczne, [w:] J. Kurczewska, H. Bojar (red.), Granice na pograniczach. Z badań społeczności lokalnych wschodniego pogranicza Polski, Warszawa.

Michna E. (2004), Od „euroentuzjazmu” do „europragmatyzmu”. Karpatorusińscy liderzy etniczni wobec jednoczącej się Europy, [w:] K. Krzysztofek, A. Sadowski (red.), Pogranicza i multikulturalizm $w$ warunkach Unii Europejskiej. Implikacje dla wschodniego pogranicza Polski, t. 2, Białystok.

Olszański T.A. (2013), Kresy Zachodnie. Miejsce Galicji Wschodniej i Wołynia w państwie ukrainskim, Warszawa.

Ossowski S. (1984), O ojczyźnie i narodzie, Warszawa.

Potaczała K. (2015), Bieszczady w PRL-u. Część trzecia, Olszanica.

Przeciszewski P. (2007), Ruś Zakarpacka - zapomniany kraj, „Więź”, nr 1.

Rymarowicz L. (2012), Iwan Franko i Wójt Łeńko, czyli znowu o Wołosatem, „Płaj. Almanach Karpacki”, z. 45.

Rymarowicz L. (2014), Wokół Wołosatego raz jeszcze, „Płaj. Almanach Karpacki”, z. 48.

Sadowski A. (1996), Od miast przygranicznych do miast pogranicza (Na podstawie miast obszaru przygranicznego wschodniej Polski), „Pogranicze. Studia Społeczne”, t. 5.

Słownik Języka Polskiego PWN, A-K (1998), M. Szymczak (red.), Warszawa.

Szczerek Z. (2010), Janukowycza będziemy cicho nienawidzić, „Nowa Europa Wschodnia”, nr 3-4.

Świdrowska E. (2012), Otoczenie społeczne granicy polsko-ukraińskiej, [w:] J. Fomina, J. Konieczna-Sałamatin (red.), Granica do naprawy. Problemy pogranicza Polski i Ukrainy.

Wilson T. M., Donnan H. (2000), Nation, state and identity at international borders, [w:] T. M. Wilson, H. Donnan (ed.), Border identities. Nation and state at international frontiers, Cambridge.

Żochowski P., Iwański T. (2015), Zakarpacie - razem, ale z boku, Komentarze OSW, nr 185; www. osw. waw. pl, [01.10.2015]

\section{Źródła internetowe:}

http://112.ua/obshchestvo/v-zakarpatskoy-obl-ma-polsko-ukrainskoy-granice-postiyatpeshehodnyy-perehod-hubnya-volosatoe-180661.html, [09.05.2015]

http://chas-z.com.ua/news/13874, [09.05.2015]

http://fkdp.pl/wp-content/uploads/2014/07/EDD-2014.pdf, [14.04.2015]

http://karpatnews.in.ua/news/68627-shostyi-kreminets-fest-bez-grantovykh-vohnestroiv-nad-holovamy-miliardy-zirok.htm, [20.09.2015] 
http://krylow.info/europejskie_dni-dobrosasiedztwa2015.html, [07.09.2015]

http://panorama-mukachevo.com/2014/04/24/85170, [09.05.2015]

http://trubyna.org.ua/novyny/polyaky-poobitsyaly-vidkryty-punkt-perehodu-na-kordoni-iz-zakarpattyam, [09.05.2015]

http://tsn.ua/ukrayina/u-zakarpatskomu-seli-lubnya-nemaye-pershoklasnikiv.htmal, [09.05.2015]

http://ua-reporter.com/taxnonomy/term/20138, [09.05.2015]

\section{Abstract}

\section{Over hill, over dale... or border as an invisible wall. The endemism of the Transcar- pathian section of the Ukrainian-Polish borderland}

The aim of the article is to introduce a neglected section of the Ukrainian-Polish borderland, Transcarpathia, within the area of the sociology of borderland. The author sheds some light on the ethnic, geographical and political peculiarity of this region, with special attention paid to its isolation from Poland, one of the oblast's close neighbours. Apart from the relevant literature (rather poor), the article is based on the author's own observations made in a few Transcarpathian villages in 2014 and 2015 as well as on their inhabitants' opinions concerning the problems with opening up the border-crossing in Lubnya. The gist of the considerations is to show different shades of Transcarpathia's isolation from Poland which results in the region's inhabitants' lack of contacts with Poles and lack of knowledge on Poland. Consequently, Lubnya and its Polish neighbour from over the mountains, Wołosate, being geographically very close, are socially and culturally quite distant, not to say - alien. The article concludes with a range theoretical conceptions that might be applied in order to understand better the reality of the Transcarpathian section of the Ukrainian-Polish borderland.

KeYwords: Transcarpathia, Ukraine, Poland, Lubnya, border-crossing, borderland, isolation 